\title{
Концептуальні підходи до організаційно-методичних технологій оптимізації медичної допомоги населенню сільськогосподарської області з хворобами крові та кровотворних органів
}

\author{
Сумський державний університет \\ Сумська обласна клінічна лікарня
}

\begin{abstract}
В статті представлено кониептуальні підходи до організаційно-методичних технологій оптимізації медичної допомоги населенню сільськогосподарської області з хворобами крові та кровотворних органів. Оптимізація медичної допомоги населенню сільськогосподарської області з хворобами крові та кровотворних органів полягає в структурній перебудові системи надання гематологічної допомоги, удосконалення ресурсної бази та підвищення рівня компетентності лікарів, щзо надають медичну допомогу населенню з хворобами крові та кровотворних органів та удосконалення управління даним видом медичної допомоги.

Ключові слова: хвороби крові та кровотворних органів, медична допомога, оптимізачія, концептуальні підходи.
\end{abstract}

\section{Вступ}

3 доров'я населення України має стійкі тенденції до погіршення $[1,2]$. До класів хвороб які мають найбільш суттєвий влив на зростання захворюваності населення його інвалідизацію та смертність відносяться і хвороби крові та кровотворних органів [3, 4]. Зростання рівня захворюваності населення на хвороби крові та кровотворних органів в Україні відмічається після аварії на ЧАЕС [5]. Деякі вчені відмічають високий рівень захворюваності населення на хвороби крові та кровотворних органів на територіях 3 розвиненою промисловістю, що зумовлено незадовільною якістю навколишнього середовища [6]. Зростання рівнів захворюваності населення на хвороби крові та кровотворних органів потребує оптимізації медичної допомоги даній категорії населення [7].

Визначення ефективних шляхів покращення здоров'я населення на сучасному етапі неможливе без удосконалення системи охорони здоров'я $[8,9]$ і в першу чергу спеціалізованої з іiі інтеграцією на первинний рівень $[10,11]$. Важливим напрямком в цьому процесі $\epsilon$ підвищення доступності медичної допомоги [12] та іiі якості $[13,14]$ при забезпеченні безпечності медичних послуг [15] шляхом впровадження сучасних організаційних та клінічних технологій.

Мета роботи - розробити концептуальні підходи до організаційно-методичних технологій оптимізації медичної допомоги населенню сільськогосподарської області 3 хворобами крові та кровотворних органів на сучасному етапі реформування галузі охорони здоров'я України.

\section{Матеріали та методи}

В ході дослідження були використані бібілосемантичний метод та метод структурно-логічного аналізу. Методичною основою дослідження був системний підхід. В якості матеріалів дослідження використані законодавчі акти України з реформування сфери охорони здоров'я в країні.

\section{Результати дослідження та їх обговорення}

Організація медичної допомоги хворим на хвороби крові та кровотворних органів - складне і багатокомпонентне поняття, яке об'єднує два аспекти: об’єктивний (організація надання медичної допомоги) та суб'єктивний (медична допомога, як вона сприймається). На рисунку нами представлена загальна схема організації медичної допомоги (МД) хворим 3 хворобами крові та кровотворних органів, що базується на трьох основних компонентах: процесі, структурі і результативності, які запропонував A. Donabedian [16] для оцінки якості медичної допомоги.

Структурна компонентна МД пацієнтам з хворобами крові та кровотворних органів характеризується і оцінюється якістю ресурсів (фінансових, кадрових, матеріально-технічних, інформаційних) та організаційних форм надання медичної допомоги. Таким чином, структура характеризує умови для надання МД даній категорії пацієнтів. Структурний аспект може визначатися як по відношенню до закладу охорони здоров'я (підрозділу, служби) 3 його ресурсним забезпеченням (кадровим, матеріально-технічним), організацією роботи, так i до кожного медичного працівника служби як первинної так i спеціалізованої МД окремо. Оцінюються його професійні якості: сума знань, умінь, компетенцій з надання медичної допомоги хворим на хвороби крові та кровотворних органів.

Процесна компонента МД хворим на хвороби крові та кровотворних органів (гематологічна медична допомога) $\epsilon$ складовою сучасного управління організацією медичної допомоги пацієнтам як 3 первинними захворюваннями крові та кровотворних органів так і $з$ тими у яких дана 
патологія розвивається на фоні хвороб інших органів та систем (визначених фізіологічних станів). Вона включає технології надання гематологічної медичної допомоги (ГМД), тобто виконання медичними працівниками своїх функцій 3 профілактики, діагностування та лікування хворих 3 хворобами крові та кровотворних органів, взаємовідносин між персоналом і пацієнтом.

Результат - це компонента системи, що відображає ефективність наданої ГМД. Оцінка за результатами включає зміни в стані здоров'я пацієнтів, які потребували медичної допомоги при хворобах крові та кровотворних органів: зниження потреби в стаціонарному лікуванні, рівня втрати працездатності, ускладнень, інвалідизації та летальності зазначеного контингенту пацієнтів.

3 позиції системного підходу всі вказані компоненти гематологічної медичної допомоги пов'язані між собою. Так, на ефективність медичної допомоги впливає наявність та якість обладнання, технологій, рівень кваліфікації персоналу, раціональність організаційної структури служби, механізми взаємодії персоналу тощо. Отже на ефективність ГМД можна впливати шляхом удосконалення ресурсного забезпечення i заходів управлінсько-організаційного характеру (структури організації медичної допомоги в цілому).

Проведене нами дослідження організації медичної допомоги пацієнтам 3 хворобами крові та кровотворних органів в закладах охорони здоров'я усіх рівнів надання медичної допомоги дорослому населенню у сільськогосподарському регіоні виявило недоліки у всіх компонентах системи гематологічної медичної допомоги.

Було встановлено, що більшість виявлених недоліків при наданні ГМД пов'язані 3 організаційноуправлінськими аспектами - структурною організацією як амбулаторної так і стаціонарної медичної допомоги на територіальному рівні, тобто відсутністю функціональної диференціації закладів охорони здоров'я за видами та інтенсивністю стаціонарної медичної допомоги 3 недостатнім ресурсним забезпеченням та кваліфікацією медичного персоналу.

Враховуючи, що результативність медичної допомоги на 80-95\% залежить від дефектів організації та управління, медичних технологій, що використовуються, а також від рівня підготовки управлінців охорони здоров'я. Тобто розв'язання проблем щодо підвищення якості та ефективності ГМД лежить у площині удосконалення структури як амбулаторно-поліклінічного i в першу чергу первинної медичної допомоги так i стаціонарного сектору медичної допомоги пацієнтам 3 хворобами крові та кровотворних органів і удосконалення механізмів управління нею.

На даному етапі функціонування системи охорони здоров'я в Україні необхідні перетворення можливі в межах структурної перебудови системи надання медичної допомоги $з$ пріоритетним розвитком первинної медикосанітарної допомоги на засадах загальної лікарської практики 3 визначенням лікаря загальної практикисімейного лікаря лікарем першого контакту який визначає медичний маршрут пацієнта та формування госпітальних округів із формуванням лікарень інтенсивного лікування і запровадження гарантованого державою безоплатного пакету медичних послуг.

При проведені теоретичного обгрунтування оптимізації організаційно-методичних технологій надання медичної допомоги хворим на хвороби крові та кровотворних органів на рівні сільськогосподарського регіону ми спиралися на ряд міжнародних документів.

Так, в Талліннській хартії «Система охорони здоров'я - добробут» (25-27 червня 2008 р.), зокрема говориться, що пацієнтам потрібно забезпечити доступ до високоякісної медичної допомоги, і впевненість у тому, що постачальники послуг у своїй роботі спираються на найсучасніші і надійні дані в медичній науці, а також використовують найбільш адекватні технології, забезпечуючи ефективність і безпеку втручань.

При цьому, щодо питань фінансування системи охорони здоров'я, у Хартії відзначається, що механізми фінансування повинні забезпечувати можливість перерозподілу ресурсів 3 метою оптимального надання медико-санітарних послуг, а «загальний характер розподілу ресурсів повинен забезпечувати необхідний баланс із метою найбільш повного задоволення поточних та прогнозованих потреб охорони здоров'я» [17].

Крім того, результати проведеного дослідження вказали на відсутність дієвого контролю якості надання ГМД та індикаторів, за якими має оцінюватися іiї ефективність. Наслідком цього $є$ збільшення неконтрольованих дефектів лікувально-діагностичного процесу, підвищення фінансових витрат, відсутність у керівників дієвих інструментів для управляння ГМД, що вкрай важливо при лікування пацієнтів 3 хворобами крові та кровотворних органів.

Спираючись на світовий досвід нами підтримана для впровадження в службу гематологічної МД індустріальна модель управління якістю медичної допомоги, яка охоплює організацію, всі види діяльності і ресурсів, орієнтована на задоволення потреб і очікувань пацієнтів та полягає в досягненні певного рівня якості при забезпеченні пацієнтів 3 хворобами крові та кровотворних органів медичною допомогою.

У сучасній індустріальній моделі управління якістю МД виділяють дві складові - зовнішню гарантію якості (похідна бюрократичної моделі) і внутрішню, основу якої складає концепція безперервного підвищення якості медичної допомоги (БПЯ). Фундаментальні положення іiї наступні:

- для отримання кращих результатів систему необхідно змінювати;

- результативність системи визначається і1ї властивостями;

- різні вкладення в систему гарантують поліпшення тільки в тій мірі, в якій вони можуть вплинути на зміну системи, тобто будь-яка діяльність (навчання, заохочення, оцінка) призводить до поліпшення, тільки якщо має місце відповідне покращення самої системи;

- змінам мають піддаватися не тільки окремі компоненти системи медичної допомоги пацієнтам 3 хворобами крові та кровотворних органів (структура, процес, результат), а і зв'язки між ними. 


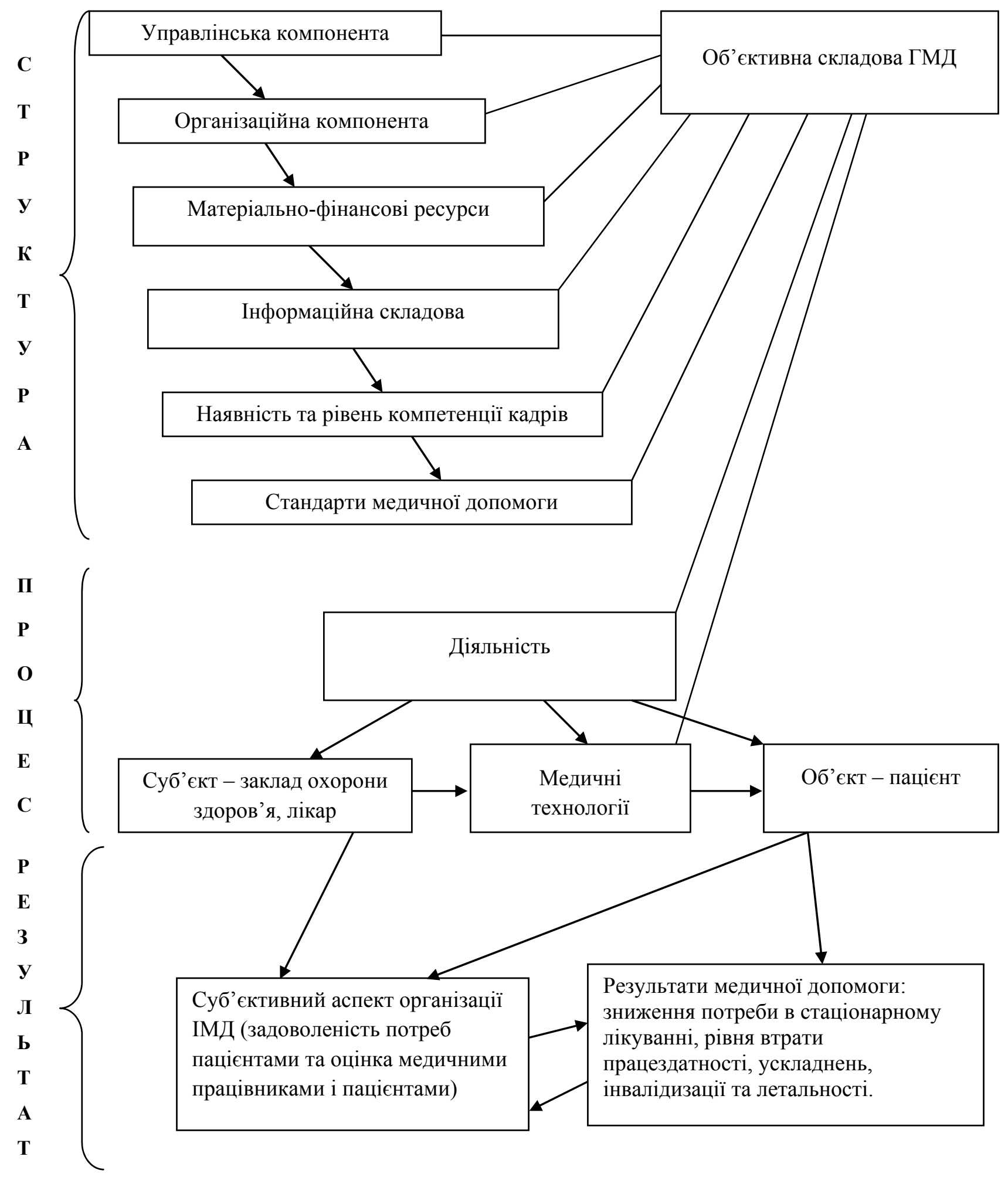

Рис. Схема організації медичної допомоги хворим з хворобами крові та кровотворних органів

Виходячи з цього безперервне підвищення якості медичної допомоги передбачає комплексний, інтегрований i динамічний підхід, спрямований на поліпшення результатів діяльності системи в цілому (системний підхід) шляхом постійної модифікації i вдосконалення як іiі складових, так і взаємозв'язків між ними, виявлення і вирішення існуючих проблем.

Результати обгрунтування було використано при розробці комплексних підходів до розвитку організаційнометодичних технологій медичної допомоги населенню 
3 хворобами крові та кровотворних органів на рівні сільськогосподарського регіону.

Стан здоров'я, тривалість та якість життя населення України значною мірою визначаються станом організації та функціонування системи охорони здоров'я, доступністю та якістю медичних послуг, що гарантують забезпечення реалізації передбаченого Конституцією України права громадян на медичну допомогу, а також ефективністю використання ресурсів галузі охорони здоров'я.

Оптимізація системи охорони здоров'я на сучасному етапі передбачає необхідність подальшого розвитку системи медичної допомоги на засадах, які мають забезпечити:

- доступність якісних медичних послуг для всіх тих, хто їх потребує відповідно до медичних показань;

- відповідність структури медичних послуг, які фінансуються за рахунок державних коштів, реальним медичним потребам різних груп населення;

- захист населення від зубожіння, пов'язаного 3 необхідністю самостійно оплачувати необхідні медичні послуги;

- підвищення ефективності використання всіх наявних у сфері охорони здоров'я видів ресурсів.

3 цією метою в діяльність закладів охорони здоров'я передбачається запровадити ефективні економічні механізми. Дане дозволяють мотивувати постачальників медичних послуг (організаторів охорони здоров'я і лікарів) водночас як до підвищення якості та ефективності медичної допомоги, так і до підвищення економічної ефективності діяльності. До таких механізмів відноситься автономізація закладів охорони здоров'я [18] та фінансування закладів охорони здоров'я за принципом оплати наданих медичних послуг в рамках гарантованого державою пакету безоплатної медичної допомоги.

Ключовою ідеєю удосконалення медичної допомоги населенню сільськогосподарської області 3 хворобами крові та кровотворних органів $є$ послідовне вирішення пріоритетної проблеми забезпечення пацієнтів 3 хворобами крові та кровотворних органів якісною, ефективною та доступною медичною допомогою шляхом оптимізації структури і процесів надання гематологічної медичної допомоги на основі наукового аналізу отриманих даних.

Розробка оптимізованої функціональноорганізаційної системи медичної допомоги населенню 3 хворобами крові і кровотворних органів проводилася нами 3 позиції системного підходу на рівні сільськогосподарської області в цілому.

Методологія створення задач, сутність кожної 3 яких спрямована на досягнення кінцевої мети: підвищення якості та доступності медичної допомоги пацієнтам 3 хворобами крові та кровотворних органів потребують вирішення конкретних питань.

Для досягнення поставленої мети ми виділили наступну групу задач:

1) Структурна перебудова системи медичної допомоги населенню крові та кровотворних органів. Рішення вказаної задачі полягає в створені на базі лікарень інтенсивного лікування спеціалізованих діагностико- консультативних амбулаторних спеціалізованих гематологічних кабінетів.

Стаціонарне лікування на вторинному рівні надання медичної допомоги відбувається в профільних спеціалізованих відділеннях лікарні інтенсивного лікування: терапевтичному, гінекологічному, хірургічному, гастроентерологічному тощо.

Спеціалізовані гематологічні стаціонарні відділення для надання медичної допомоги вказаній категорії пацієнтів формуються в складі лікарень інтенсивного лікування другого рівня. Їх потужність розраховується в залежності від рівнів поширеності хвороб крові та кровотворних органів на території.

Для надання викоспеціалізованої медичної допомоги пацієнтам 3 хворобами крові та кровотворних органів формується стаціонарне гематологічне відділення в складі обласної клінічної лікарні. Це дасть можливість забезпечити надання необхідних консультацій пацієнтам лікарями-спеціалістами. На базі цієї лікарні формується лабораторія для проведення високозатратних та високотехнологічних досліджень для верифікації діагнозу 3 метою призначення обгрунтованої схеми лікування. На базі даного відділення створення обласного центру телемедичних консультацій.

Закладом охорони здоров'я первинного та постійного контакту хворих 3 хворобами крові та кровотворних органів з медичною системою $\epsilon$ амбулаторії загальної практики-сімейної медицини. Сімейні лікарі проводять цільову диспансеризацію вказаної категорії населення включаючи моніторинг стану здоров'я та регулювання схем лікування.

2) Ресурсне забезпечення. Рішенням цієї задачі $є$ забезпечення базовим діагностичним інструментальним обладнанням; базовим лабораторним обладнанням; базовим обладнанням для лікування пацієнтів, які $€$ необхідними для впровадження сучасних клінікодіагностичних технологій, що грунтуються на даних 3 доведеною ефективністю. Передбачається наявність комп'ютерної техніки $з$ доступом до системи Інтернет та підключенням до Електронної системи охорони здоров'я 3 метою створення регіонального реєстру населення 3 хворобами крові та кровотворних органів та звітування перед Національною службою здоров'я України.

3) Кадрове забезпечення. Рішення цієї задачі передбачає забезпеченість кваліфікованими лікарямигематологами спеціалізованих гематологічних структурних підрозділів закладів охорони здоров'я області 3 ïx постійним професійним розвитком.

3 метою забезпечення ефективної медичної допомоги населенню 3 хворобами крові та кровотворних органів на рівні первинної медичної допомоги необхідна теоретична та практична підготовка лікарів загальної практики-сімейних лікарів 3 актуальних питань гематології з регулярним інформуванням останніх про методи діагностики та лікування хворих з хворобами крові та кровотворних органів.

Підвищення рівня знань лікарів-спеціалістів закладів охорони здоров'я спеціалізованої та високоспеціалізованої медичної допомоги, які в своїй клінічній практиці зустрічаються 3 пацієнтами 3 
патологією крові та кровотворних органів 3 актуальних питань діагностики захворювань крові та кровотворних органів і лікування пацієнтів.

Для цього передбачено:

- безперервну післядипломну підготовку спеціалістів шляхом:

а) організації навчального центру на базі спеціалізованого відділення обласної лікарні;

б) залучення до цієї роботи професорськовикладацького складу профільних кафедр ВМНЗ IIIIV рівнів акредитації;

- стажування сімейних лікарів та лікарівспеціалістів закладів охорони здоров'я спеціалізованої та високоспеціалізованої медичної допомоги в спеціалізованих підрозділах або закладах охорони здоров'я;

- стажування лікарів-гематологів регіону в провідних клініках за кордоном, що дасть можливість як оволодіти сучасними технологіями надання ГМД так і перейняти досвід організації спеціалізованої гематологічної медичної допомоги.

\section{4) Безперервне підвищення якості} гематологічної медичної допомоги передбачає: запровадження комплексної програми безперервного підвищення якості, формування системи безпеки пацієнтів в закладах охорони здоров'я, впровадження системи індикаторів оцінки якості медичної допомоги системою, гематологічними підрозділами та окремими медичними працівниками. Якість, доступність та своєчасність медичної допомоги при хворобах крові та кровотворних органів також забезпечується розробкою маршрутів пацієнтів для кожної адміністративної території області в залежності від діагнозу та стану пацієнта.

5) Загальне управління гематологічною службою на рівні області забезпечує департамент охорони здоров'я обласної державної адміністрації для чого введена посада обласного позаштатного лікаря-гематолога експерта. Для підвищення відповідальності органів охорони здоров'я в обов'язки заступників начальників територіальних управлінь/відділів охорони здоров'я вноситься персональна їх відповідальність за організацію гематологічної допомоги населенню. Роботу в цьому напрямку вони організовують через медичних директорів закладів охорони здоров'я. Об'єктом управління виступає департамент охорони здоров'я обласної державної адміністрації, а суб'єктами управління - заклади охорони здоров'я в яких надається медична допомога при хворобах крові та кровотворних органів. Блок наукового регулювання включає дані з доведеною ефективністю 3 питань профілактики, діагностики та лікування населення 3 хворобами крові та кровотворних органів, законодавчі акти $з$ питань реформування системи надання медичної допомоги в країні.

\section{Висновки}

Результатом дослідження стало обгрунтування та розробка організаційно-методичних технологій оптимізації медичної допомоги населенню 3 хворобами крові та кровотворних органів на рівні сільськогосподарського регіону в сучасних умовах реформування системи охорони здоров'я в країні.

Перспективи подальших досліджень пов'язані з вивченням ефективності впровадження запропонованих організаційно-методичних технологій оптимізації медичної допомоги населенню сільськогосподарської області з хворобами крові та кровотворних органів.

\section{Література}

1. Щорічна доповідь про стан здоров’я населення, санітарно-епідемічну ситуацію та результати діяльності системи охорони здоров’я України. 2015 рік / за ред. Шафранського В. В. ; МОЗ України, ДУ «УІСД МОЗ України». Київ, 2016. - 452 с.

2. Чепелевська Л. А. Сучасні медико-демографічні проблеми в Україні та шляхи їх подолання / Л. А. Чепелевська, О. П. Рудницький // Україна. Здоров’я нації. - 2015. - № 3 (35). - С. 39-43.

3. Щорічна доповідь про стан здоров’я населення, санітарно-епідемічну ситуацію та результати діяльності системи охорони здоров’я України. 2014 рік [монографія] / за ред. О. Квіташвілі. - К., 2015. - 460 с.

4. Батманова І.Ю. Динаміка захворюваності дорослого населення Донецької області на хвороби крові та кровотворних органів / Батманова І.Ю., Слабкий Г.О. // Вісник соціальної гігієни та організації охорони здоров’я України. - 2006. - № 3. - С.29-34.

5. Авраменко О. І. Стан здоров'я населення після аварії на Чорнобильській АЕС (за даними Київської області) / Авраменко О.І., Сиваченко Т.П. // Лікарська справа. - 1993. - № 7. - С. 6-10.

6. Батманова I.Ю. Стан гематологічного здоров'я дорослого населення екологічно несприятливого промислового регіону / Батманова І.Ю., Слабкий Г.О. // Тези доповідей науково-практичної конференції «Актуальні питання клінічної медицини та післядипломної освіти». Ялта, 13-14 травня 2004 року. - Ялта, 2004. - С. 27-28.

7. Батманова І.Ю. Щодо оптимізації організації гематологічної допомоги на рівні великого промислового регіону // Матеріали ХІ конгресу світової федерації Українських лікарських товариств. - Полтава-Київ-Чикаго, 2006. C. 665 .

8. Новая европейская политика здравоохранения: Здоровье-2020. - ЕРБ ВОЗ. - Копенгаген, 2012. - 125 с.

9. Принциии організації оптимальної моделі системи охорони здоров’я // Журнал «Внутренняя медицина» 6(6) 2007 // http://www.mif-ua.com/archive/article/3618. 
10. Слабкий Г. О. Пріоритетний розвиток первинної медико-санітарної допомоги на засадах сімейної медицини / Г. О. Слабкий, І. С. Зозуля, А. І. Зозуля // Сімейна медицина. - 2014. - № 3 (53). - С. $25-27$.

11. Вовченко В.В. Досвід реформування первинної медико-санітарної допомоги на засадах сімейної медицини в Полтавській області (методичний посібник для організаторів охорони здоров'я та лікарів загальної практики-сімейної медицини) / В.В. Вовченко, В.П. Лисак, О.М. Ключко та ін. - Полтава, 2002. - 153 с.

12. Смиянов B.A. Оценка доступности медицинской помощи населению: опыт регионального исследования / А.Н. Костенко, Н.Д. Свитайло, В.А. Смиянов // Социс. - 2013. - № 12. - С. 133-136.

13. Сміянов B.A. Внутрішній аудит - основа управління якістю медичної допомоги в закладі охорони здоров'я / Сміянов В.A // Wiadomosci Lekarskie. - 2014, tom LXVII, nr 2. cz. II. - P. 381-383.

14. Сміянов В.A. Медико-соціальне обгрунтування моделі управління якістю медичної допомоги на основі внутрішнього аудиту на рівні закладу охорони здоров’я : автореф. дис. ... д-ра мед. наук : спец. 14.00 .33 «Соціальна медицина» / В.А. Сміянов. - Харків, 2015. - 38 с.

15. Федосюк P. M. Безпека пацієнта - глобальний виклик сучасній медицині / Р. М. Федосюк, О. М. Ковальова // Неонатологія, хірургія та перинатальна медицина. - 2013. - Т. III, №3 (9). - С. 19-25.

16. Donabedian A. Evaluating the quality of medical care. Midank memorial Fund quarterli, 44: 166-206 (1966).

17. Таллиннская хартия: Системы здравоохранения для здоровья и благосостояния. - Копенгаген : ЕРБ ВОЗ, 2008 [Электронный ресурс]. - Режим доступа: http://www.euro.who.int/_data/assets/pdf_file/0007/88612/ E91438R.pdf. Название с экрана.

18. Особливості підготовки закладів охорони здоров'я до автономізації в умовах впровадження нової системи їх фінансування / Скрип В.В., Миронюк І.С., Слабкий Г.О. // Wiadomości Lekarskie. - 2018, tom LXXI, № 4. - С. 936.

Дата надходження рукопису до редакиіï: 02.10.2019 р.

\begin{abstract}
Концептуальные подходы к организационнометодическим технологиям оптимизации медицинской помощи населению сельскохозяйственной области с заболеваниями крови и кроветворных органов
\end{abstract}

Смиянов В.А., Горох В.В. Сумской национальный университет Сумская областная клиническая больница

В статье представлены концептуальные подходы к организационно-методическим технологиям оптимизации медицинской помощи населению сельскохозяйственной области с заболеваниями крови и кроветворных органов. Оптимизация медицинской помощи населению сельскохозяйственной области с заболеваниями крови и кроветворных органов состоит в структурной перестройке системы оказания гематологической помощи, усовершенствовании ресурсной базы и повышении уровня компетентности врачей, оказывающих медицинскую помощь населению с заболеваниями крови и кроветворных органов, а также усовершенствовании управления данным видом медицинской помощи.

Ключевые слова: заболевания крови и кроветворных органов, медицинская помощь, оптимизация, концептуальные подходы.

\section{Conceptual approaches to organizational and methodological technologies for optimization of medical aid to the population of agricultural region for diseases of blood and hemopoietic organs}

Smiianov V.A., Horoh V.V. Sumy National University Sumy Regional Clinical Hospital

The article presents the conceptual approaches to organizational and methodological technologies for optimization of medical aid to the population of agricultural region with diseases of blood and hemopoietic organs. Optimization of medical aid to the population of agricultural region with diseases of blood and hemopoietic organs consists in the restructuring of the system of providing hematological care, improving the resource base and increasing the level of competence of physicians who provide medical care to the population with diseases of blood and hemopoietic organs and perfection of the management in this type of medical care.

Key words: diseases of blood and hemopoietic organs, medical care, optimization, conceptual approaches.

\section{Відомості про авторів}

Сміянов В.А. - д.м.н., професор, зав. кафедри громадського здоров’я Сумського державного університету; 40000, Україна, м. Суми, вулиця Римського-Корсакова, 2.

Горох В.В. - головний лікар Сумської обласної клінічної лікарні; 40022, Україна, м. Суми, вул. Троїцька, 48. 